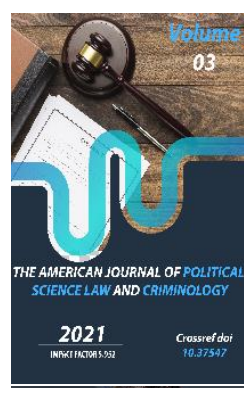

\title{
Democratic Legal Culture: How Strong Are Values?
}

\section{Zafar Ergashev}

The Research Institute Of Legal Policy Under The Ministry Of Justice, Uzbekistan

\section{ABSTRACT}

Raising democratic legal culture is one of the key aspects of the policy of the Republic of Uzbekistan. A number of normative legal acts of the Republic of Uzbekistan adopted in this sphere.

This article focuses on describing measures of the Government of Uzbekistan to improve people's knowledge of democracy. Furthermore, this work also includes the results of the current research on evaluating people's opinions about democracy.

\section{KEYWORDS}

Democracy, legal culture, legal awareness, normative legal acts.

\section{INTRODUCTION}

Today, serious attention is paid to raise democratic legal culture as a result of the ongoing reforms in the political, legal, socioeconomic and cultural-educational spheres in our country. Only in 2019-2020, a number of normative legal acts are adopted in this direction, such as Decree of the President of the Republic of Uzbekistan 
"On radical improvement of the system of raising legal awareness and legal culture in society" (DP-5618, 09/01/2019), Regulation of the President "On additional measures to ensure the supremacy of the Constitution and laws, to strengthen public control in this regard and to raise legal culture in society" (RP-4551, 13/12/2019), Regulation of the Cabinet of Ministries of the Republic of Uzbekistan “On approval of the Regulation on monitoring and evaluation of measures to improve legal culture in society" (No. 342, 20/04/2019) Regulation of the Cabinet of Ministries of the Republic of Uzbekistan "On measures for further improvement of the system of legal assistance and promotion of legal information to people" (No. 741, 06/09/2019).

Based on the objectives of these normative legal acts, a number of measures are being taken by the relevant government agencies to improve democratic legal culture. For instance, the Ministry of Justice launched the National legal web portal of the Republic of Uzbekistan - huquqiyportal.uz. The portal integrates more than 10 information systems of the Ministry of Justice, in particular, lex.uz, official websites of justice agencies and institutions, bolahuquqlari.uz portals and provides citizens with convenient access to legal information.

Moreover, the portal of legal information "Advice.uz" (e-maslahat.uz) was launched by the Ministry of Justice of the Republic of Uzbekistan. Through this portal, citizens of the Republic of Uzbekistan, foreign citizens, and stateless persons can receive free legal advice online.

For information: 71,000 questions, which received through the portal of legal information "Advice.uz" in 2020, were provided with legal adviceonline. 24 percent of online appeals are related to social protection issues, 21 percent to labor relations and 15 percent to family relations.

In order to maintain the portal of legal information "Advice.uz", a non-governmental non-profit organization "Madad" was established. "Madad" NGO provides free primary legal assistance to citizens by providing legal advice and clarification.

For information: free legal aid was provided to 41,000 citizens on legal issues by "Madad" NGO in 2020. 14 percent of these issues are related to the judiciary, 13 percent to social protection, and 11 percent to family relations.

A procedure for monitoring and evaluation of measures to improve legal culture in society was introduced in order to assess the ongoing measures to improve democratic legal culture. The purpose of this procedure is to increase the effectiveness of legal information campaigns directed to raise legal awareness and legal culture of people, as well as to strengthen the responsibility of government agencies and organizations in this regard.

For information: according to the report of the Ministry of Justice of the Republic of Uzbekistan, 601,823 advocacy events were held by government agencies and organizations in 2020. 171,150 oral legal information campaigns were conducted. 78,335 lectures, 57,364 roundtables, 31,112 seminars, 4,339 conferences were organized on the basis of these events.

Besides, the Regional Rule of Law Index was introduced. The Index includes indicators of democratic legal culture of people, such as pressure on citizens and journalists who enjoy the freedom of speech and expression, the 
development of civil society institutions, and citizen's participation in the local decisionmaking process.

For information: the Regional Rule of Law Index is based on 182 indicators: 111 indicators are formed on the basis of statistics which are maintained by 24 organizations, including the Supreme Court, the Prosecutor General's Office, the Ministry of Justice, and the Ministry of Internal Affairs; 71 indicators are formed on the basis of the results of sociological survey among people and legal experts.

In addition, based on the above legislation, various public events are being held to promote democratic legal culture in family, mahalla, educational institutions, government agencies and non-governmental organizations.

Naturally, the results of reforms in this direction would be interesting for everyone. For this purpose, the Research Institute of Legal Policy under the Ministry of Justice in collaboration with regional justice agencies conducted sociological researches in order to assess the level of democratic legal culture of citizens. The first sociological research was conducted in
June-September

2019

on "Current issues of legal awareness and legal culture in society" and the second research was carried out in JulyNovember 2020 on "Raising legal awareness and legal culture in society: current challenges and factors of success".

1,075 respondents from 70 districts (cities) across the country took part in the survey that was conducted as part of the sociological research in 2020.

In this regard, the results of the analysis of the answers given by the respondents to some questions of the survey on democratic legal culture are noteworthy.

For instance, the major part of the respondents (75.8\%) considered that it would be better for a particular country to accept democracy, i.e. the system of governing a country through elected representatives, than other different political systems, namely autocracy, dictatorship, aristocracy.

Moreover, more of the respondents (61.1\%) positively assessed the level of implementation of democratic reforms. This can be seen in the following diagram: 


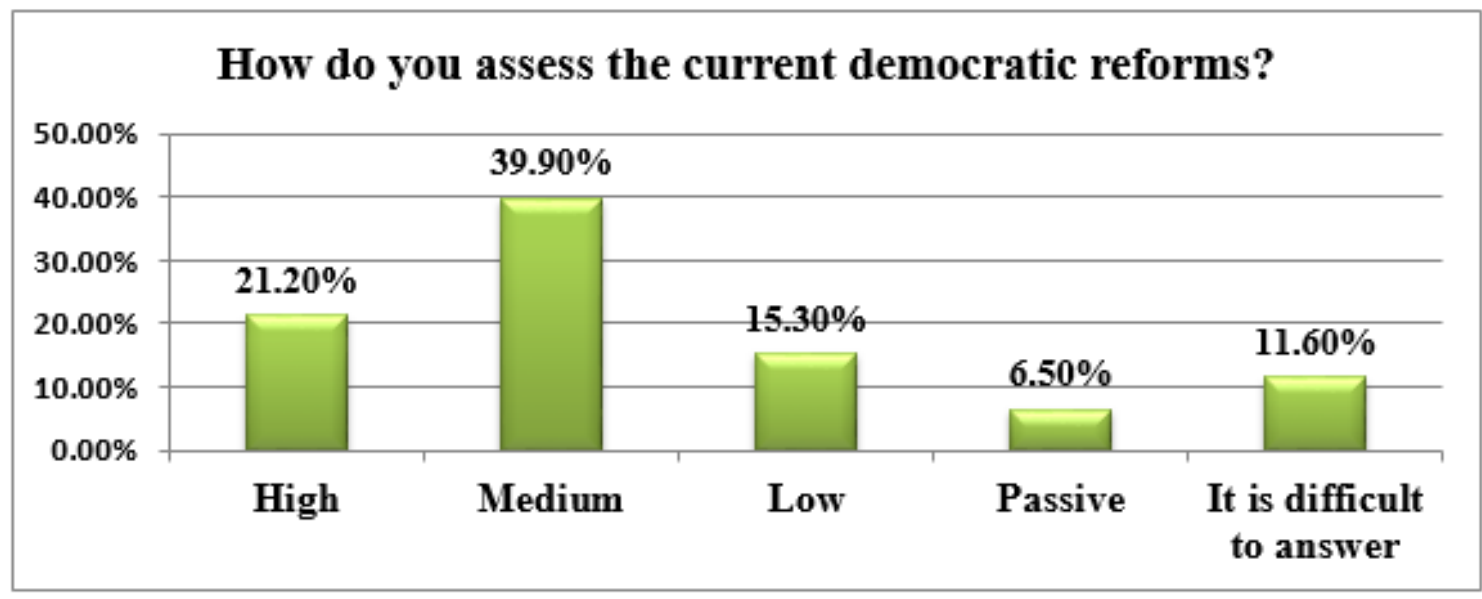

Furthermore, a greater part of the respondents (86.3\%) believed that public order could be This can be seen in maintained through democratic governance.

the following diagram:

mantined through democratic governance.

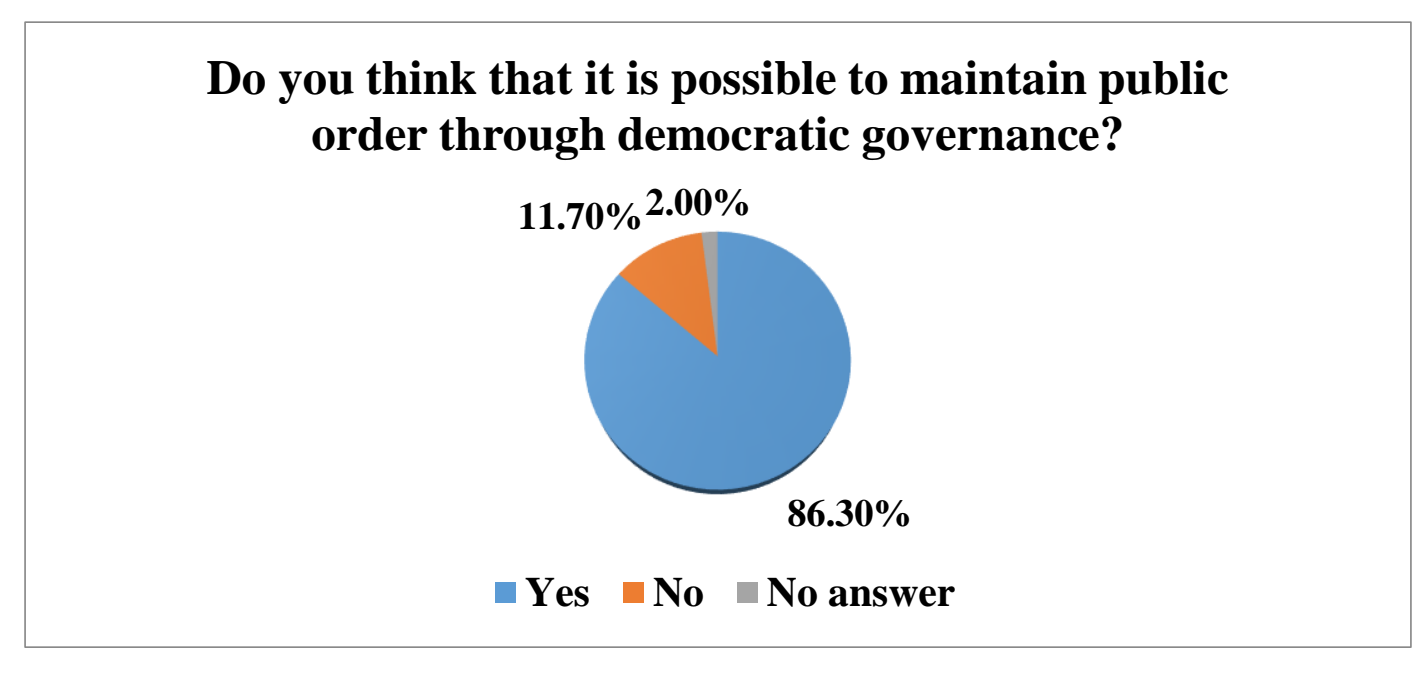

In addition, the Majority of the respondents (83.5\%) considered that democracy was better than other forms of government. This can be seenin the following diagram: 


\section{Do you think that democracy is better than other forms of government?}

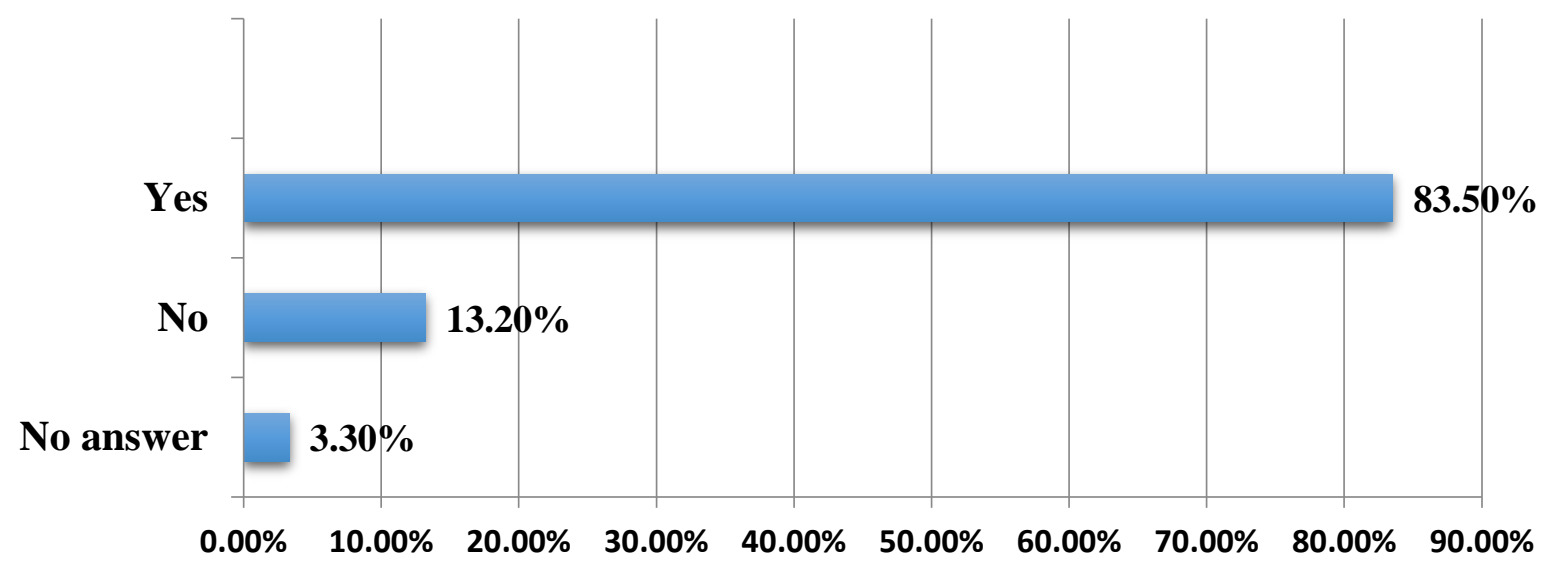

The results of the sociological survey show that people have positive ideas towards democracy. The majorities of respondents consider democratic governance system as the most effective system and support the acceleration of democratic reforms. They believe that democratic governance has a positive impact on maintaining public order and developing economy.

This is the result of reforms, including adopted normative legal acts, in recent years to promote democratic legal culture.

Of course, it is necessary to enhance the reforms in the field of raising democratic legal culture, without being limited to the current results. A number of measures in this field are planned to implement in the Republic of Uzbekistan in 2021.

For instance, the President of the Republic of Uzbekistan Shavkat Mirziyoyev addressed the Oliy Majlis and the people of Uzbekistan on 29 December 2020. In his Address, he stressed to establish public participation and control in the implementation of normative legal acts.
Moreover, he noted to introduce a system of "public hearings" and "public monitoring", and to involve civil society institutions, the media and citizens in this process.

Furthermore, it is planned to create an integrated system aimed at further enhancing the role of women in society and public administration, to develop the draft law "On free legal aid", to strengthen social control over government expenses, to strengthen the legal framework for ensuring freedom of speech and comprehensive development of the media in the state program for implementation of the national Action Strategy on five priority development areas 2017-2021 in the year of youth support and public health promotion.

In conclusion, it should be noted that great attention is paid to raise the democratic legal culture in Uzbekistan. The people have positive ideas towards democracy. It is expected to continue the implementation of measures aimed at developing this sector. 
Doi: https://doi.org/10.37547/tajpslc/Volumeo3Issue05-14

\section{REFERENCES}

1. Decree of the President of the Republic of Uzbekistan "On radical improvement of the system of raising legal awareness and legal culture in society" < https://lex.uz/docs/-4149765> accessed 04 May 2021

2. President Shavkat Mirziyoyev's Address to the Oliy Majlis on 29 December $2020<$ https://president.uz/en/lists/view/4057> accessed 04 May 2021

3. Handbook about the results of the sociological survey on "Current issues of legal awareness and legal culture in society" (2019) <https://hsti.uz/?p=25715> accessed 04 May 2021 